\title{
The emergence of endothermy in the black-footed and Laysan albatrosses
}

\author{
W.R. Dawson ${ }^{1}$, G.C. Whittow ${ }^{2}$ \\ ${ }^{1}$ Museum of Zoology and Department of Biology, The University of Michigan, Ann Arbor, MI 48109, USA \\ ${ }^{2}$ Department of Physiology, John A. Burns School of Medicine, University of Hawaii, Honolulu, HI 96822, USA
}

Accepted: 14 January 1994

\begin{abstract}
Eggs with pip-holes of the black-footed (Diomedea nigripes) and Laysan (Diomedea immutabilis) albatrosses were exposed to various air temperatures in the range $20-35^{\circ} \mathrm{C}$ in order to detect signs of incipient endothermy in late embryos. No evidence of endothermy was found. In contrast, the $\mathrm{O}_{2}$ consumption of most hatchlings increased in response to cooling, the $\mathrm{O}_{2}$ consumption at an air temperature of $25^{\circ} \mathrm{C}$ exceeding that between 34 and $35^{\circ} \mathrm{C}$ by $40 \%$. In a minority of hatchlings this response was not seen. It was suggested that endothermy may develop at some time during the $24 \mathrm{~h}$ after hatching.
\end{abstract}

Key words: Thermoregulation - Endothermy - Embryos - Hatchlings - Albatrosses, Diomedea

\section{Introduction}

Recent studies of the embryos of three species of tropical seabirds failed to provide evidence of thermoregulation, demonstrating instead the sudden appearance of a thermoregulatory capability in the hatchling (Matsunaga et al. 1989; Mathiu et al. 1991, 1992, 1994). The eggs of the three species investigated (brown noddy, Anous stolidus; wedge-tailed shearwater, Puffinus pacificus; sooty tern, Sterna fuscata) belonged to two different Orders - the Procellariiformes and Charadriiformes - but they shared a number of common characteristics. In the three species, the sequence of events during pipping of the egg was similar (Pettit and Whittow 1983, 1985; Whittow 1985) and the eggs were relatively small $(37-60 \mathrm{~g})$.

Abbreviations: bm, body mass; $\mathrm{C}_{\mathrm{total}}$, total thermal conductance of tissues and plumage; $f$, respiratory frequency; $F \mathrm{E}_{\mathrm{O}_{2}}$, fractional concentration of oxygen in air leaving chamber; $\mathrm{FI}_{\mathrm{O}_{2}}$, fractional concentration of oxygen in air entering chamber; $T_{a}$, air temperature; $T_{b}$, deep-body temperature; $\dot{V}$, air-flow rate; $\dot{\mathrm{O}}_{2}$, oxygen consumption

Correspondence to: G.C. Whittow
The present report stems from the opportunity to measure the development of endothermy in two sympatric species of albatross that nest on Midway Atoll in the north-western Hawaiian Islands. The sequence of events during pipping was similar in the two species but it differed from that in the shearwater, tern and noddy. The albatross eggs were also considerably larger [285$305 \mathrm{~g}$, Pettit et al. (1982)]. Both features may have a bearing on the appearance of thermoregulation: the initial event during pipping of the albatross egg is puncture of the internal shell membrane of the egg by the embryo's beak (Pettit et al. 1982). Penetration of the internal shell membrane and chorio-allantoic membrane is followed by a substantial increase in the $\mathrm{O}_{2}$ uptake by the embryo (Pettit et al. 1982). This may be a prerequisite for an increase in $\mathrm{VO}_{2}$ and regulatory thermogenesis in response to cooling of the egg i.e., for incipient endothermy. Secondly, the large eggs of the albatross may, through their thermal inertia, buffer the embryos from sudden changes in temperature and also permit them to store efficiently small increments in heat production in response to cooling.

The available evidence did not lend much support for embryonic thermoregulation in the black-footed albatross. Howell and Bartholomew (1961) found that the temperature of pipped eggs exposed to a $T_{\mathrm{a}}$ of $19-23^{\circ} \mathrm{C}$ declined steadily. However, the cooling rate of eggs at such low $T_{\mathrm{a}}$ may well eclipse any evidence of a nascent endothermic response (Whittow and Tazawa 1991). In the present investigation eggs and hatchlings were exposed to graded reductions of $T_{\mathrm{a}}$ in order not to obscure the presence of a small endothermic response.

\section{Materials and methods}

Study site; birds. The study was conducted on Sand Island, Midway

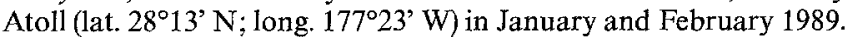
Midway has a breeding population of approximately 7000 breeding pairs of black-footed albatross (Diomedea nigripes) and 175000 breeding pairs of Laysan albatross (Diomedea immutabilis) (Harrison 1990). The two species differ slightly in the size of their eggs 
(Grant et al. 1982) and hatchlings (Pettit et al. 1982) but they breed at the same time of year and in contiguous areas at Midway. Eggs and hatchlings were collected from an area to the southwest of the main runway of the Naval Air Facility and another area on the north-western edge of the old taxiway. The eggs and hatchlings were brought to a temporary laboratory established in the Terminal Building and returned to the marked nest site $47 \mathrm{~h}$ later.

In the absence of the egg or hatchling, the parent bird readily incubated a substituted infertile egg and equally readily accepted back its own returned egg or hatchling. Only eggs with pip-holes (Pettit et al. 1982) were collected, representing the final stage of embryonic development before hatching. Hatchlings were all less than $24 \mathrm{~h}$ old and their plumage was dry before they were exposed to different $T_{\mathrm{a}} \mathrm{s}$.

Procedure. Each egg or hatchling was exposed to a $T_{\mathbf{a}}$ within the range $20-35^{\circ} \mathrm{C}$ (eggs) or $15-35^{\circ} \mathrm{C}$ (hatchlings). Each exposure lasted for $3 \mathrm{~h}$ and during the final 15 minutes of the exposure measurements were made of $\dot{V} \mathrm{O}_{2}$ and $f$ of the embryo or hatchling. The egg or hatchling was contained in a plexiglass chamber with a capacity of approximately 11 . Dry air was pumped through the chamber at a rate of $375-637 \mathrm{ml} \cdot \mathrm{min}^{-1}$ for eggs and $731-794 \mathrm{ml} \cdot \mathrm{min}^{-1}$ for hatchlings. At the end of the 3-h period, the egg or hatchling was removed from the chamber and $T_{\mathrm{b}}$ measured. The chamber containing the egg or hatchling was immersed in a thermostatically-controlled water bath (Grant), the temperature of which could be changed to provide the requisite $T_{\mathrm{a}}$ within the egg/hatchling chamber. The chamber $T_{\mathrm{a}}$ was monitored throughout the exposure. Before each exposure the hatchling or egg was weighed and the length and width of the egg determined.

Techniques. The airflow into the chamber (VI) was measured by means of a flowmeter (Brooks) and the fractional $\mathrm{O}_{2}$ concentrations of air entering and leaving the chamber were determined with an Oxygen Analyser (Ametek Applied Electrochemistry, Model S-3A/ II). Drierite and Ascarite were used as desiccant and $\mathrm{CO}_{2}$ absorbant, respectively. The $\mathrm{O}_{2}$ analyser was connected to an Omniscribe recorder (Houston Instruments) to produce a continuous record of the $\mathrm{O}_{2}$ content of the chamber air. The $\dot{V} \mathrm{O}_{2}$ of the egg or hatchling was calculated from $\dot{V} \mathrm{I}$ and the difference in the fractional $\mathrm{O}_{2}$ concentration between air entering and leaving the chamber:

$\underset{\left(\mathrm{ml} \cdot \mathrm{min}^{-1}\right)}{\dot{V} \mathrm{~m}_{2}}=\underset{\left(\mathrm{ml} \cdot \min ^{-1}\right)}{\dot{V}} \cdot \frac{F \mathrm{IO}_{2}-F \mathrm{EO}_{2}}{\left(1-F \mathrm{EO}_{2}\right)}$

The $\mathrm{O}_{2}$ consumption was corrected to standard temperature and pressure and, as the measurements were made on dry air, all values for $\dot{V} \mathrm{O}_{2}$ are at STPD. $f$ was measured by direct observation of the hatchling or the beak of the embryo in pip-holed eggs.

In order to measure the $T_{\mathrm{b}}$ of embryos in eggs with pip holes, a Yellow Springs Instrument (YSI) thermistor probe (No. 423) was inserted through the pip hole so that the tip was between the folded limbs and the body of the embryo; a similar probe was used to record cloacal temperatures in the hatchling. $T_{\mathrm{a}}$ in the chamber was measured by means of a YSI probe (No. 401). All thermistor probes were used in conjunction with a YSI Telethermometer (No. 46 TUC) and all probes were calibrated against a thermometer readable to $0.025^{\circ} \mathrm{C}$ (Brooklyn P-M Thermo Co.).

Samples of down plumage were taken from three areas in the hatchlings and the length of the down was measured with a ruler. Eggs and hatchlings were weighed on an Ohaus Dial-O-Gram balance to the nearest $0.1 \mathrm{~g}$. Egg dimensions were measured to the nearest $0.05 \mathrm{~mm}$ with a Manostat dial caliper.

Derived values. The only derived value calculated was $C_{\text {total }}$ of the tissues and plumage in the hatchlings. It was calculated by converting the $\mathrm{VO}_{2}$ of the hatchling to heat production (in $\mathrm{mW}$ ), assuming that $1 \mathrm{ml} \mathrm{O} \mathrm{O}_{2} \equiv 20.08 \mathrm{~J}$, and dividing by the difference in body and air temperature $\left(T_{b}-T_{a}\right)$. The thermal conductance so calculated was not corrected for evaporative water loss.
Statistical procedures. The measure of variation used in this paper is the standard deviation. Differences in $\mathrm{VO}_{2}, T_{\mathrm{b}}$ or $f$ between selected $T_{\mathrm{a}} \mathrm{s}$ and durations of exposure were evaluated by a $t$-test taking the $5 \%$ level of probability to be significant. When consecutive measurements were made on the same embryo, the statistical comparison of the measured values was made by a paired-comparison $t$-test (Swinscow 1981). Correlation coefficients were calculated between $f$ and $T_{\mathrm{a}}$. Statistical significance of differences in the characteristics of the down were assessed by analysis of variance and Tukey's procedure (Steel and Torrie 1960). Each egg or hatchling was used only once.

\section{Results}

\section{Climatic conditions}

The climatic conditions at Midway at the time of our investigation represent the conditions to which the eggs and hatchlings would be exposed should the parent birds be derelict in their incubation or brooding duties. The conditions can be described as cool, wet and windy, especially for the sub-tropics (Table 1), in keeping with the fact that the study coincided with the winter period at Midway.

\section{Eggs with pip holes}

Egg dimensions. The dimensions and mass of the eggs of the two species are given in Table 2. The eggs of the black-footed albatross were larger than those of the Laysan albatross as reported before (Grant et al. 1982).

Oxygen consumption. The $\dot{V} \mathrm{O}_{2}$ of the black-footed albatross eggs with pip holes declined with decreasing $T_{a}$ within the approximate range $25-35^{\circ} \mathrm{C}$ (Fig. 1). However, $\dot{V} \mathrm{O}_{2}$ at $20^{\circ} \mathrm{C}$, the lowest $T_{\text {a }}$ to which the eggs were exposed, was not significantly different from that at $25^{\circ} \mathrm{C}$ $(t=0.52 ; 0.6>P>0.5)$. Six eggs were exposed to a $T_{\mathrm{a}}$ of $20^{\circ} \mathrm{C}$ for $4 \mathrm{~h}, 1 \mathrm{~h}$ longer than the period used in most of our tests. A paired comparison $t$-test revealed that the

Table 1. Climatic conditions at Midway during the period January 15-February 5, 1989

\begin{tabular}{llll}
$\begin{array}{l}\text { Maximum } \\
\begin{array}{l}\text { temperature } \\
\left({ }^{\circ} \mathrm{C}\right)\end{array}\end{array}$ & $\begin{array}{l}\text { Minimum } \\
\text { temperature } \\
\left({ }^{\circ} \mathrm{C}\right)\end{array}$ & $\begin{array}{l}\text { Rainfall } \\
\left(\mathrm{cm} \cdot \text { day }^{-1}\right)\end{array}$ & $\begin{array}{l}\text { Peak wind } \\
\text { velocity } \\
\left(\mathrm{m} \cdot \mathrm{s}^{-1}\right)\end{array}$ \\
\hline 22.4 & 16.8 & 0.51 & 11.5 \\
$(18.3-25)$ & $(12.2-22.2)$ & $(0-4.93)$ & $(4.1-20.6)$ \\
\hline
\end{tabular}

Mean values with ranges in parentheses

Table 2. Egg dimensions in the two species of albatross

\begin{tabular}{lcc}
\hline & Black-footed albatross & Laysan albatross \\
\hline Egg mass $(\mathrm{g})$ & $268.9 \pm 14.3(33)$ & $240.8 \pm 12.6(19)$ \\
Egg length $(\mathrm{mm})$ & $108.3 \pm 3.8(33)$ & $107.3 \pm 3.2(18)$ \\
Egg width $(\mathrm{mm})$ & $71.8 \pm 1.7(33)$ & $68.9 \pm 2.1(18)$ \\
\hline
\end{tabular}

Mean values $\pm S D$. Number of eggs in parentheses 

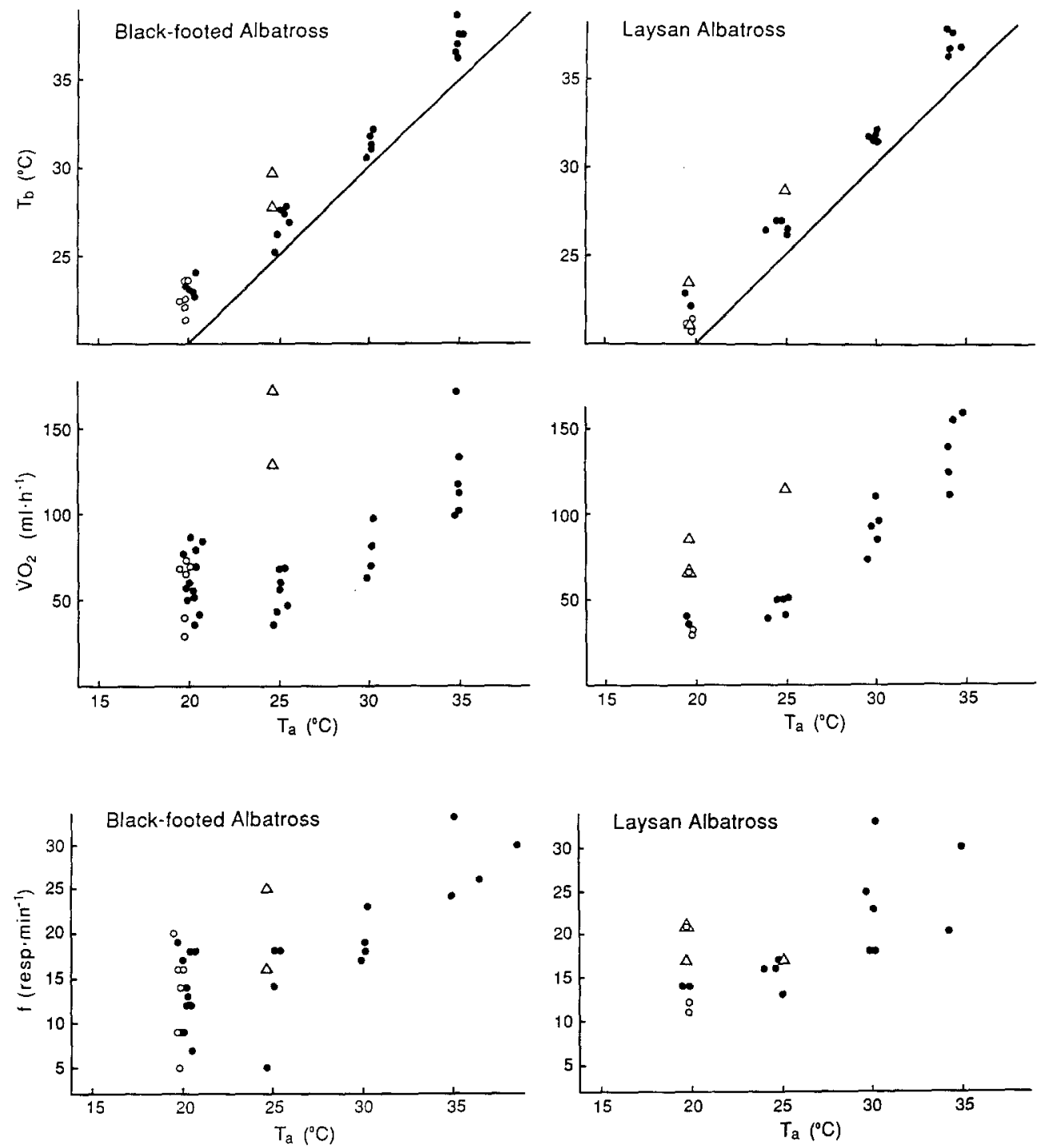

Fig. 1. Relation of body temperature $\left(T_{\mathrm{b}} ;\right.$ upper panels $)$ and oxygen consumption $\left(\dot{V} \mathrm{O}_{2}\right.$; lower panels) to air temperature $\left(T_{\mathrm{a}}\right)$. for embryonic blackfooted and Laysan albatross in eggs with pip holes, $=$ embryos exposed to a particular $T_{\mathrm{a}}$ for $3 \mathrm{~h} ; \mathrm{O}=$ exposure to a $T_{\mathrm{a}}$ of $20^{\circ} \mathrm{C}$ for $4 \mathrm{~h}$ in blackfooted or $6 \mathrm{~h}$ in Laysan embryos; $\triangle=$ eggs in the process of hatching during the measurements. The solid line in the upper panels links equivalent values of $T_{\mathrm{b}}$ and $T_{\mathrm{a}}$

Fig. 2. Relation of respiratory frequency $(f)$ to air temperatures $\left(T_{\mathrm{a}}\right)$. for embryonic blackfooted and Laysan albatross in eggs with pip holes $=$ embryos exposed to a particular $T_{\mathrm{a}}$ for $3 \mathrm{~h} ; \mathrm{O}=$ embryos exposed to a $T_{\mathrm{a}}$ of approximately $20^{\circ} \mathrm{C}$ for $4 \mathrm{~h}$ in black-footed or $6 \mathrm{~h}$ in Laysan albatross; $\triangle=$ eggs in the process of hatching during the measurement period
$\dot{V} \mathrm{O}_{2}$ after $4 \mathrm{~h}$ was significantly lower than after exposure for $3 \mathrm{~h}(t=11.65 ; P<0.001)$. However, the mean $\dot{V} \mathrm{O}_{2}$ $\left(58.00 \mathrm{ml} \cdot \mathrm{h}^{-1}\right.$ after a 4 -h exposure to a $T_{\mathrm{a}}$ of $20^{\circ} \mathrm{C}$ was not significantly different from that $\left(57.38 \mathrm{ml} \cdot \mathrm{h}^{-1}\right)$ after a $3-\mathrm{h}$ exposure to a $T_{\mathrm{a}}$ of $25^{\circ} \mathrm{C}(t=0.02 ; P>0.9)$. Two eggs with pip holes that were exposed to a $T_{\mathrm{a}}$ of $25^{\circ} \mathrm{C}$ were in the process of hatching at the time that measurements of $\dot{V} \mathrm{O}_{2}$ were being made. In each instance, the $\dot{V} \mathrm{O}_{2}$ of embryos in the hatching egg was considerably higher than that of eggs that were not hatching (Fig. 1).

The data for the Laysan albatross eggs resembled those for the black-footed albatross (Fig. 1). Three eggs were exposed to a $T_{\mathrm{a}}$ of approximately $20^{\circ} \mathrm{C}$ for an additional $3 \mathrm{~h}$. At the end of the 6-h exposure, the $\dot{V} \mathrm{O}_{2}$ had, on average, diminished by $21 \%$ from the value after $3 \mathrm{~h}$ of exposure. Two eggs with pip holes were hatching during the measurement of $\dot{V} \mathrm{O}_{2}$, one at a $T_{\mathrm{a}}$ of $25^{\circ} \mathrm{C}$ and one at $20^{\circ} \mathrm{C}$. In each instance, the $\dot{V} \mathrm{O}_{2}$ was substantially higher than in eggs that were not hatching. One of the eggs that was cooled for $6 \mathrm{~h}$ was in the process of hatching (it was also hatching during the measurement of $\dot{V} \mathrm{O}_{2}$ after cooling for $3 \mathrm{~h}$ ); although the $\dot{\mathrm{VO}} \mathrm{O}_{2}$ of its embryo was lower after $6 \mathrm{~h}$ than after $3 \mathrm{~h}$ at this $T_{\mathrm{a}}$, the $\dot{V} \mathrm{O}_{2}$ after $6 \mathrm{~h}$ was still higher than that of other eggs at the same $T_{\mathrm{a}}$ that had not progressed beyond the establishment of a pip hole (Fig. 1).

Body temperature. The $T_{\mathrm{b}}$ of the embryos in black-footed albatross eggs with pip holes declined with diminishing $T_{\mathrm{a}}$. However, these embryos all remained $0.4-3.7^{\circ} \mathrm{C}$ warmer than their surroundings (Fig. 1). The $T_{\mathrm{b}}$ of embryos in six eggs that were exposed to a $T_{\mathrm{a}}$ of $20^{\circ} \mathrm{C}$ for $4 \mathrm{~h}$ were not significantly lower than those of six other eggs that were exposed for $3 \mathrm{~h}(t=0.74 ; 0.5>P>0.4)$. Two embryos that were in the process of hatching during the 3-h exposure to $25^{\circ} \mathrm{C}$ both had relatively high $T_{\mathrm{b}}$ (Fig. 1).

The Laysan albatross eggs provided essentially similar data, with the additional observation that exposure of three eggs to a $T_{\mathrm{a}}$ of $20^{\circ} \mathrm{C}$ for $6 \mathrm{~h}$ resulted in significantly lower embryonic $T_{\mathrm{b}}$ than did exposure of the same eggs for $3 \mathrm{~h}(t=7.61 ; 0.02>P>0.01)$. One egg at $25^{\circ} \mathrm{C}$ was hatching during the exposure and the $T_{\mathrm{b}}$ of its embryo was higher than that of any other egg at $25^{\circ} \mathrm{C}$ (Fig. 1). In another hatching egg at a $T_{\mathrm{a}}$ of $20^{\circ} \mathrm{C}$, the embryonic $T_{\mathrm{b}}$ was also higher than that in other eggs under similar conditions.. However, after a further 3-h exposure to this 
$T_{a}$, the $T_{\mathrm{b}}$ of this embryo had declined to a level similar to that of the other two embryos exposed to $20^{\circ} \mathrm{C}$ for $6 \mathrm{~h}$ (Fig. 1).

Respiratory frequency. The $f$ of embryos in eggs with pip holes declined with decreasing $T_{\mathrm{a}}$ in the black-footed albatross (Fig. 2). Overall, a statistically significant correlation existed between $f$ and $T_{\mathrm{a}}(r=0.756 ; P<0.001)$. However, the values at $20^{\circ} \mathrm{C}$ were not significantly lower than those at $25^{\circ} \mathrm{C}(t=0.92 ; 0.4>P>0.3)$. In four out of six eggs cooled for an additional hour, $f$ was lower but the differences were not statistically significant $(t=1.86$; $0.2>P>0.1$. The highest $f\left(25 \cdot \mathrm{min}^{-1}\right)$ at a $T_{\mathrm{a}}$ of $25^{\circ} \mathrm{C}$ was recorded from one of the two eggs that were hatching during the period of measurements at this $T_{\mathrm{a}}$ (Fig. 2).

$f$ also diminished with decreasing $T_{\mathrm{a}}$ in Laysan albatross embryos (Fig. 2) and a statistically significant correlation existed between $f$ and $T_{\mathrm{a}}(r=0.751 ; P<0.001)$. In two eggs that were exposed to a $T_{\mathrm{a}}$ of $20^{\circ} \mathrm{C}$ for $6 \mathrm{~h}$, the embryonic $f$ declined further to a level below that of the embryos after a 3-h exposure (Fig. 2). In one egg exposed to a $T_{\mathrm{a}}$ of $20^{\circ} \mathrm{C}$ for $6 \mathrm{~h}$, the embryo hatched during the period of observation. $f$ was actually greater in the hatchling at the end of $6 \mathrm{~h}$ than in the hatching embryo in situ in the egg at the end of a 3-h exposure (Fig. 2).

\section{Hatchlings}

Oxygen consumption. Over the range of $T_{\mathrm{a}}$ of $25-34.5^{\circ} \mathrm{C}$, the $\mathrm{VO}_{2}$ of the black-footed albatross hatchlings was higher at lower $T_{\mathrm{a}}$ (Fig. 3). However, between 22.6 and $14.7^{\circ} \mathrm{C}$, the $\dot{V} \mathrm{O}_{2}$ declined with decreasing $T_{\mathrm{a}}$. Thus, the mean $\dot{V} \mathrm{O}_{2}$ was highest at a $T_{\mathrm{a}}$ of approximately $25^{\circ} \mathrm{C}$, and at this $T_{\mathrm{a}}$ the mean $\dot{V} \mathrm{O}_{2}$ was $140 \%$ of the mean value at $T_{a}$ between 33.1 and $34.5^{\circ} \mathrm{C}$. The hatchlings shivered at $T_{\mathrm{a}}$ between 14.7 and $30.3^{\circ} \mathrm{C}$. In one exposed to a $T_{\mathrm{a}}$ of $22.4^{\circ} \mathrm{C}$, the $\dot{\mathrm{O}}_{2}$ was conspicuously lower than that of the other hatchlings exposed to similar $T_{\mathrm{a}}$ (Fig, 3). Another hatchling, at $19.5^{\circ} \mathrm{C}\left(T_{\mathrm{a}}\right)$, had an even lower $\dot{V} \mathrm{O}_{2}$. Both hatchlings $(\mathrm{bm}=219.0$ and $224.5 \mathrm{~g}$ versus the average value of $207.9 \pm 22.8$ ) shivered. Another hatchling that showed an elevated $\dot{V} \mathrm{O}_{2}$ at a $T_{a}$ of $25.1^{\circ} \mathrm{C}$ had hatched about $2 \mathrm{~h}$ prior to being placed in the chamber.

Laysan albatross hatchlings (mean bm $=196.3 \pm 24.1 \mathrm{~g}$ ) were significantly smaller $(t=2.04 ; 0.05>P>0.02)$ than those of the black-footed albatross $(207.9 \pm 22.8 \mathrm{~g})$. In most of the former, the relationship between $\mathrm{O}_{2}$ and $T_{a}$ resembled that shown by their black-footed congeners (Fig. 3). However, there were more Laysan hatchlings (five) in which $\dot{V} \mathrm{O}_{2}$ did not appear to be augmented at lower $T_{a}$. In these birds, the $V \mathrm{O}_{2}$ was clearly lower than that of other Laysan hatchlings at the same $T_{2}$. The relatively low values for $\dot{V} \mathrm{O}_{2}$ occurred between $T_{\mathrm{a}}$ of 18.9 and $27.5^{\circ} \mathrm{C}$. The bm of three of these hatchlings $(160.7,189.5$ and $194.9 \mathrm{~g}$ ) were lower than the average value $(196.3 \mathrm{~g})$ but only one was more than one standard deviation below the mean. The $\mathrm{VO}_{2}$ of two Laysan hatchlings that subsequently became hypometabolic was followed over the entire 3-h period that they were exposed to the altered $T_{\mathrm{a}}$. There was no evidence of any transient increase in $\dot{V} \mathrm{O}_{2}$ during the earlier part of the exposure.

Body temperature. The $T_{\mathrm{b}}$ of black-footed albatross hatchlings was stable between $T_{\mathrm{a}}$ of 32.3 and $34.5^{\circ} \mathrm{C}$ (Fig. 3). However, it declined at lower $T_{a}$. The steepest decline occurred between $T_{a}$ of 14.7 and $19.8^{\circ} \mathrm{C}$, when the $\mathrm{VO}_{2}$ was also declining (Fig. 3). The two hatchlings in which $\mathrm{VO}_{2}$ was low at lower $T_{\mathrm{a}}$, were also moderately hypothermic (Fig. 3). The results for the Laysan albatross hatchlings were very similar but the hypothermia in the hatchlings with low values for $\mathrm{VO}_{2}$ was more pronounced (Fig. 3).

Respiratory frequency. Much scatter was evident in the $f$ values of both species (Fig. 4). Hypothermia was accompanied by relatively low values. In the three hatchling Laysan albatross tested at $14.6-14.9^{\circ} \mathrm{C}$, the lowest $T_{\mathrm{a}}$ to
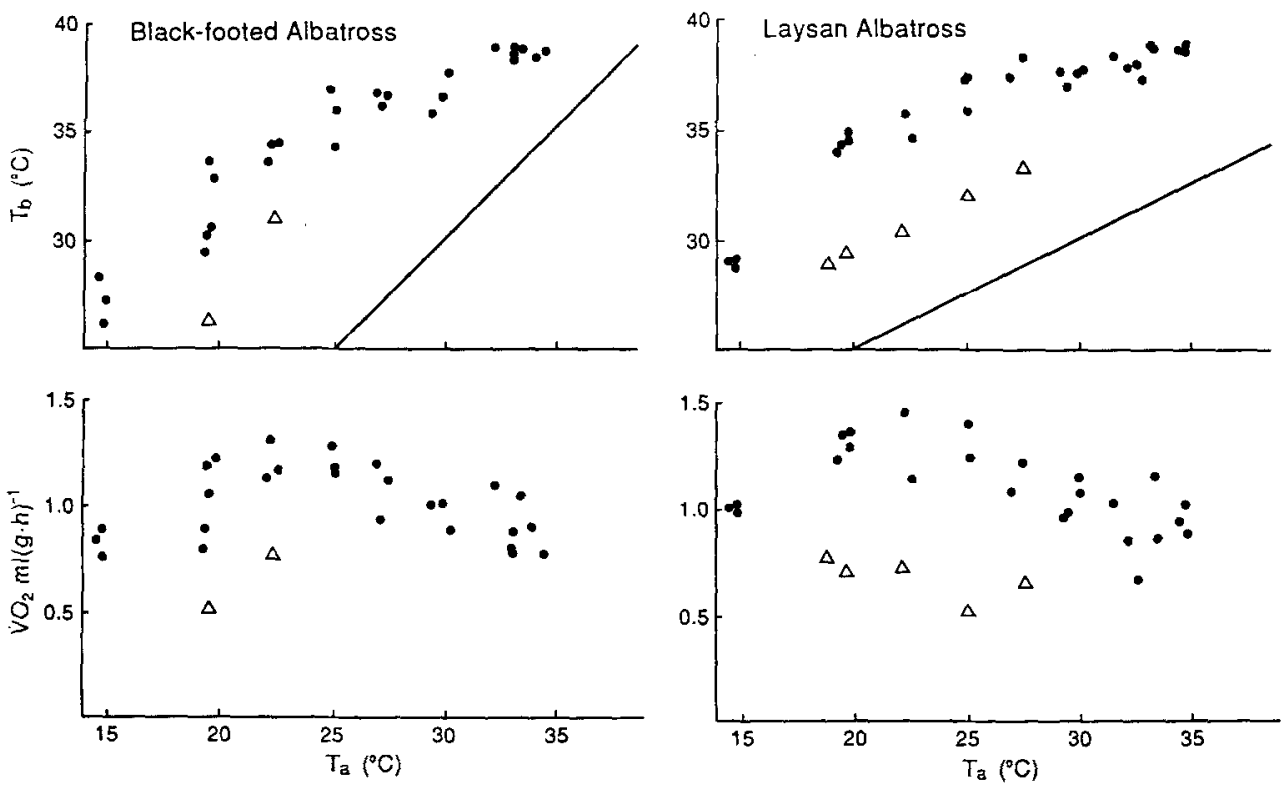

Fig. 3. Deep-body temperature $\left(T_{\mathrm{b}}\right.$, upper panels) and oxygen consumption $\left(\mathrm{VO}_{2}\right.$; lower panels) of black-footed and Laysan albatross hatchlings at various air temperatures $\left(T_{\mathrm{a}}\right)$. The solid line in the upper panels links equivalent values of $T_{\mathrm{b}}$ and $T_{\mathrm{a}} \cdot \triangle=$ hatchlings in which $\dot{V} \mathrm{O}_{2}$ and $T_{\mathrm{b}}$ were relatively low 


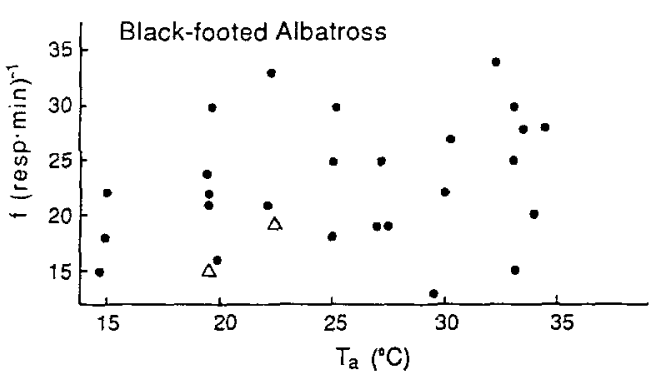

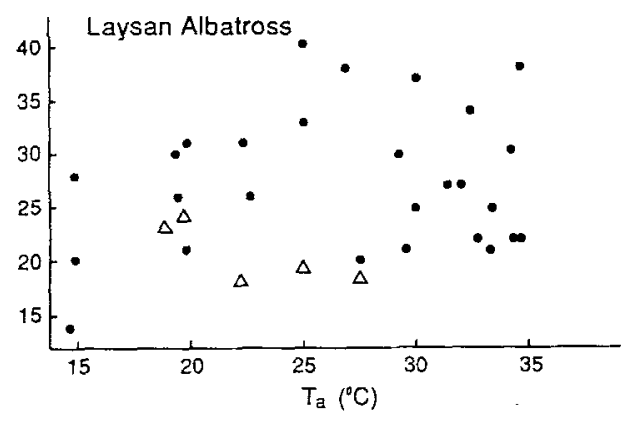

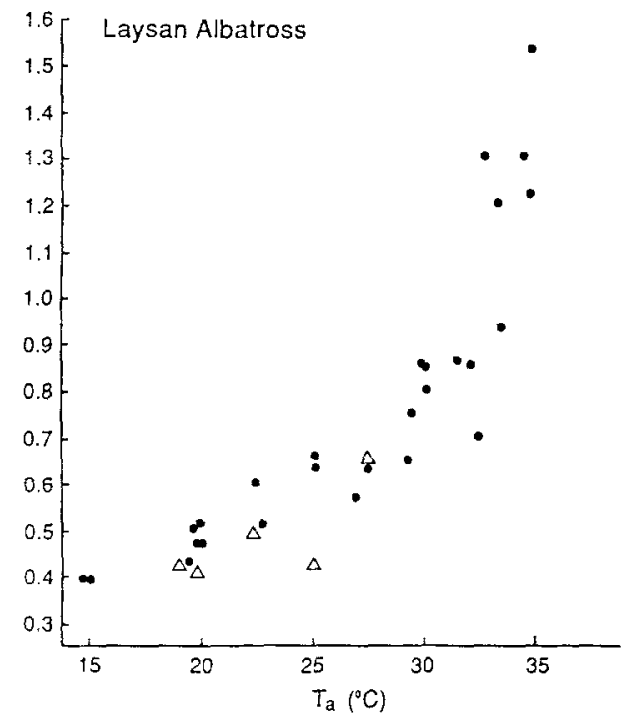

Fig. 4. Respiratory frequency (f) of black-footed and Laysan albatross hatchlings at different air temperatures $\left(T_{a}\right)$. $\triangle=$ hatchlings in which the $\dot{\mathrm{V}} \mathrm{O}_{2}$ and $T_{\mathrm{b}}$ were relatively low for the $T_{\mathrm{a}}$ to which they were exposed

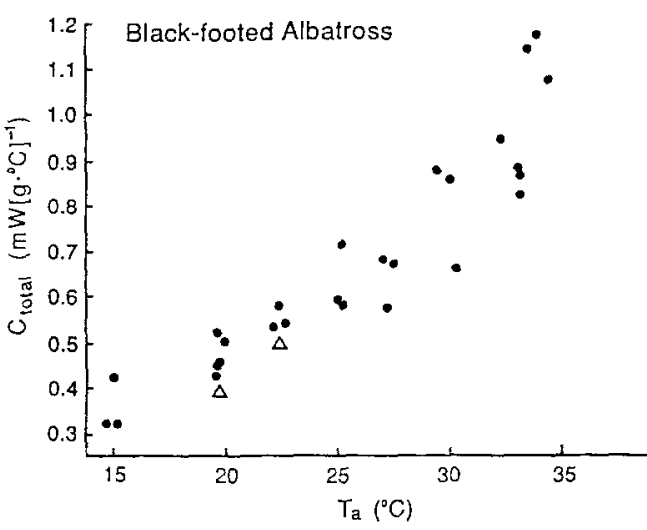

which any hatchlings were exposed, shivering was slight and $\dot{V} \mathrm{O}_{2}, T_{\mathrm{b}}$ (Fig. 3) and $f$ (Fig. 4) all were relatively low. In contrast, in one hatchling at a $T_{\mathrm{a}}$ of $25.1^{\circ} \mathrm{C}$, shivering was very pronounced and $\dot{V} \mathrm{O}_{2}, T_{\mathrm{b}}$ and $f$ were relatively high.

Total thermal conductance. Total thermal conductance of the tissues and plumage of the black-footed albatross hatchlings was lowest (mean value $=0.37 \pm 0.05 \mathrm{~mW} \cdot \mathrm{g}^{-1}$ ${ }^{\circ} \mathrm{C}^{-1}$ ) at the lowest $T_{\mathrm{a}}$ to which the hatchlings were exposed (Fig. 5). At higher $T_{\mathrm{a}}, C_{\text {total }}$ increased exponentially. In the two hatchlings that failed to show a significant increase in $\dot{\mathrm{O}}_{2}$ and became hypothermic at lower $T_{\mathrm{a}}$ (Fig. 3), both showed low values for $C_{\text {total }}$.

A similar relationship between $C_{\text {total }}$ and $T_{\mathrm{a}}$ was evident in Laysan albatross hatchlings (Fig. 5). The lowest mean thermal conductance $\left(0.40 \pm 0.0 \mathrm{~mW} \cdot \mathrm{g}^{-1} \cdot{ }^{\circ} \mathrm{C}-1\right)$ was similar to that of the black-footed albatross, but the highest value (at a $T_{\mathrm{a}}$ of $34^{\circ} \mathrm{C}$ or higher) was greater in the Laysan $\left(1.36 \pm 0.16 \mathrm{~mW} \cdot \mathrm{g}^{-1 .}{ }^{\circ} \mathrm{C}^{-1}\right)$ than in the blackfooted $\left(1.15 \pm 0.07 \mathrm{~mW} \cdot \mathrm{g}^{-1} \cdot{ }^{\circ} \mathrm{C}^{-1}\right)$ albatross. As in the latter species, the lowest values at a particular $T_{\mathrm{a}}$ were recorded from hatchlings that became hypothermic and, consequently, were relatively hypometabolic.

Down. In the black-footed albatross, analysis of variance revealed no significant differences $(P>0.05)$ in the number of barbules per feather among the three regions from which down feathers were plucked (Table 3); this was confirmed by the use of $t$-tests between individual pairs of regions. However, significant $(P<0.05)$ regional differences existed in down length, the barbules being longest on the back and shortest on the wing.

As in the black-footed albatross, no significant difference was observed in the number of barbules per down feather between the three regions (Table 3) in the Laysan albatross hatchlings. A significant difference in barbule length did exist between the dorsal and ventral regions $(P<0.05)$, but not between the ventral region and the

Table 3. Down characteristics of hatchlings of the black-footed and Laysan albatross

\begin{tabular}{lcl}
\hline & $\begin{array}{l}\text { Black-footed } \\
\text { albatross (6) }\end{array}$ & $\begin{array}{l}\text { Laysan } \\
\text { albatross }(7)\end{array}$ \\
\hline $\begin{array}{l}\text { Down length (mm) } \\
\text { Dorsum }\end{array}$ & $20.9 \pm 8.8$ & $22.5 \pm 11.4$ \\
Abdomen & $16.8 \pm 6.8$ & $15.9 \pm 9.3$ \\
Left forearm & $13.4 \pm 5.3$ & $14.5 \pm 6.9$ \\
Number of barbules per feather & \\
Dorsum & $26.5 \pm 11.4$ & $26.1 \pm 13.8$ \\
Abdomen & $18.2 \pm 6.5$ & $27.3 \pm 9.5$ \\
Left forearm & $19.8 \pm 2.9$ & $24.6 \pm 4.2$ \\
\hline
\end{tabular}

Mean values $\pm S D$ shown. Number of hatchlings in parentheses 
wing. The down was longest on the dorsal region. One hatchling from which down samples were taken had become hypothermic at a $T_{\mathrm{a}}$ of $27.5^{\circ} \mathrm{C}$ and its $\dot{V} \mathrm{O}_{2}$ had not increased. Its down length was within the range of that of the other hatchlings. It was remarkable in that the number of barbules per feather (47) on the dorsal region was the highest recorded at any site in either species. However, comparison of the two species revealed that none of the differences in number or length of barbules between comparable areas (Table 3) was statistically significant.

\section{Discussion}

The data from the eggs with pip-holes revealed that the $\dot{V} \mathrm{O}_{2}$ of the albatross embryos declined with $T_{\mathrm{a}}$ within the range $25-35^{\circ} \mathrm{C}$. At the lowest $T_{\mathrm{a}}\left(20^{\circ} \mathrm{C}\right)$ to which the eggs were exposed, the $\dot{V} \mathrm{O}_{2}$ appeared to be maintained at, or close to, the levels at $25^{\circ} \mathrm{C}$ (Fig. 1). At first sight this would appear to indicate a feeble degree of endothermy (Tazawa et al. 1989), but the experiments in which the eggs were cooled for longer than $3 \mathrm{~h}$ revealed further reductions in embryonic $\mathrm{VO}_{2}$ and $T_{b}$. Albatross eggs are large and apparently require longer than $3 \mathrm{~h}$ at a lowered $T_{\mathrm{a}}$ before they reach a "quasi-equilibrium" state (Matsunaga et al. 1989). Thus, the albatross eggs resembled those of the brown noddy, wedge-tailed shearwater, and sooty tern (Mathiu et al. 1991, 1992, 1994) in that the $\dot{V O}_{2}$ did not increase and was not maintained during cooling, despite the fact that the sequence of events during pipping in the albatross differed from that in the other species. These results indicate that the appearance of endothermy was not linked to any particular pipping sequence. As each event during pipping results in a potential increase in the rate at which the embryo can acquire $\mathrm{O}_{2}$ it must be concluded that the developmental trajectory of endothermy was not "oxygen limited" (Tazawa et al. 1988). After a 6-h exposure to a $T_{\mathrm{a}}$ of $19.8^{\circ} \mathrm{C}$, the $\dot{V} \mathrm{O}_{2}$ of Laysan albatross embryos had diminished with a $Q_{10}$ of 2.49. Thus, there was no evidence that embryos in eggs with pip-holes responded to a lowered $T_{\mathrm{a}}$ with any indication of incipient endothermy.

However, embryos that were in the process of hatching were able to sustain substantially higher values for $\dot{V} \mathrm{O}_{2}$ and $T_{\mathrm{b}}$, at lower $T_{\mathrm{a}}$, than were embryos that had not advanced beyond the pip hole stage. A similar phenomenon was observed in eggs (with pip-holes) of the brown noddy (Mathiu et al. 1991), wedge-tailed shearwater (Mathiu et al. 1992) and sooty tern (Mathiu et al. 1994), and the possible reasons for the higher heat production were postulated (Mathiu et al. 1991). They included partial emancipation from the physical constraints imposed by the eggshell on movements of the limbs, and inflation of the lungs.

In the noddy, shearwater and tern, hatching appeared to be a watershed in the emergence of endothermy: a detectable thermoregulatory response to cold was absent in eggs with pip-holes but conspicuous in hatchlings. Also, in the two species of albatross, endothermy appeared first in the hatchling. However, evidence was obtained in the albatross for a transitional stage in birds at this stage.
Thus, in five Laysan and two black-footed albatross hatchlings, the $\dot{V} \mathrm{O}_{2}$ did not increase during cooling and these birds became relatively hypothermic (Fig. 3). It is worthy of note that the $\mathrm{V}_{2}$ of such hatchlings approached that of embryos in hatching eggs. In contrast, the $\mathrm{VO}_{2}$ of hatchlings that showed a clear endothermic response to cooling was substantially higher than these levels. In other words, an endothermic response requires a higher metabolic rate than that achieved during the act of hatching. It is of interest that Fisher (1975) identified the posthatching phase as being the time of greatest chick mortality in the Laysan albatross. In the light of the present findings this may be related to the transitional nature of this stage in its life history.

In the present work a "hatchling" was defined as "within $24 \mathrm{~h}$ of hatching". Thus, it is not possible to state whether the hatchlings that did not display a well-defined endothermic response were younger, in hours, than those that did. That thermoregulatory responses can change rapidly is apparent from Misson's (1977) work. Misson presented evidence for qualitative differences in the response of hatchlings of the domestic fowl to cold between the ages of 2 and $8 \mathrm{~h}$ after hatching. Klaassen and Bech (1992) noted that resting metabolic rate and, to a lesser extent, summit metabolic rate were correlated with bm rather than age. We found little evidence in albatross to support the hypothesis that the transitional stage in endothermy was linked to low bm in the hatchlings. However, the Laysan albatross hatchlings were somewhat smaller than the black-footed albatross hatchlings and this could have been a factor in the higher incidence in the former of failure to increase their $\dot{V} \mathrm{O}_{2}$ at lower $T_{\mathrm{a}}$. The failure of $\mathrm{VO}_{2}$ to increase at such $T_{\mathrm{a}}$ did not appear to be linked to the duration $(3 \mathrm{~h})$ of exposure: $\mathrm{VO}_{2}$ was followed continuously in two hatchling Laysan albatross but neither showed an endothermic response early in the exposure. That the development of endothermy is not simply related to hatchling age is suggested by the response shown by a hatchling black-footed albatross that had hatched approximately $2 \mathrm{~h}$ prior to being placed in the chamber (Fig. 3).

The data for down length and number of barbules provide little basis for believing that the hatchlings in which the $\mathrm{VO}_{2}$ did not increase were less well insulated than were other hatchlings. The data for $C_{\text {total }}$ appear to be consistent with this belief, for thermal conductance was generally lowest in hatchlings displaying the greatest degree of hypothermia (Fig. 5). However, this conclusion should be regarded with considerable caution because calculations of thermal conductance from measurements of $\mathrm{VO}_{2}$ underestimate $C_{\text {total }}$ when $T_{\mathrm{b}}$ is decreasing, the magnitude of the underestimate being related to the degree of hypothermia. Thus, $C_{\text {total }}$ is calculated from the ratio:

$\frac{\dot{V} \mathrm{O}_{2}}{T_{\mathrm{b}}-T_{\mathrm{a}}}$

When an animal is cooling the numerator should include a measure of the rate at which the body heat content is decreasing. This could not be done in the present investi- 
gation; consequently the values for $C_{\text {total }}$ are probably too low at the lower $T_{\mathrm{a}}$. A similar explanation may hold, in part, for the decline in $C_{\text {total }}$ with decreasing $T_{\mathrm{a}}$ both in the present investigation and in that conducted on the Antarctic petrel, Thalassoica antarctica, by Bech et al. (1991). Hatching $T_{b}$ diminished at lower $T_{\mathrm{a}}$ in the albatross and the petrel, and calculated $C_{\text {total }}$ also diminished.

An alternative explanation is that the albatross hatchlings were less mature than those of the other species (wedge-tailed shearwater, brown noddy, sooty tern) and that, consequently, endothermy should appear later in the albatross. This could explain the appearance of a transitional stage in the albatross hatchlings, but not in the other species [or, incidentally, in the Antarctic petrel Bech et al. (1991)]. Comparisons between the albatross and shearwater hatchlings are of particular interest in this regard, because they are all tropical procellariiform species.

Based on the relative yolk content of the freshly laid eggs, the wedge-tailed shearwater and the two species of albatross have been characterized as semi-precocial (Pettit et al. 1984). Thus, the maturity of their hatchlings appears to be roughly comparable. Nevertheless, the designation "semi-precocial" is a broad one and semi-precocial hatchlings may be ranked according to their specific yolk content. When this is done, the Laysan and blackfooted albatross emerge as being "less" semi-precocial than the wedge-tailed shearwater (Pettit et al. 1984). Further support for this categorization comes from a comparison of the thermogenic responses of the shearwater and albatross hatchlings. The mean $\dot{V O}_{2}$ of the shearwater hatchlings at a $T_{\mathrm{a}}$ of $25^{\circ} \mathrm{C}$ exceeded that in the thermoneutral zone by a factor of 1.7 (Mathiu et al. 1992). In the two species of albatross, the $\dot{V O}_{2}$ at $T_{\mathrm{a}}$ of $25.1{ }^{\circ} \mathrm{C}$ exceeded that at a $T_{\mathrm{a}}$ between 34 and $35^{\circ} \mathrm{C}$ by a factor of only 1.4. The relatively greater thermogenic response of the shearwater would be in keeping with its postulated greater maturity at hatching. This conclusion should be qualified because the thermoneutral zone of the albatross hatchlings was not defined, although inspection of Fig. 3 suggests that at a $T_{\mathrm{a}}$ between 34 and $35^{\circ} \mathrm{C}, \dot{V} \mathrm{O}_{2}$ was, in fact, minimal. In addition, the albatross hatchlings are larger and, on these grounds alone, would be expected to cool more slowly and to need lower thermogenic responses than would the smaller shearwater.

The results of the present study concur with those of Howell and Bartholomew (1961). The latter investigators did not measure $\mathrm{VO}_{2}$ but they found that Laysan and black-footed albatross hatchlings, unlike embryos in pipped eggs, were able to stabilize their $T_{\mathrm{b}}$ in the face of a lowered environmental temperature, provided that their plumage had dried.

In conclusion, no evidence of endothermy was detected in late embryos of the Laysan and black-footed albatross. In contrast, most hatchlings responded to cooling with an increased $\dot{\mathrm{V}} \mathrm{O}_{2}$; a minority of hatchlings failed to do so.

Acknowledgements. This study was supported by a grant from the National Geographic Society. Permits for the work were pro- vided by the U.S. Fish and Wildlife Service; special thanks are due to Stewart I. Fefer for his assistance. The Commanding Officer at Midway, Lieutenant Commander G.E. McMillan and Lieutenant D.W. Messing kindly provided laboratory space and helped in numerous other ways. Captain Jerry Falls, Harbor Master, Mr. Sweeney Fernando of the Weather Office, Mr. Bud Newton, Base Services Inc., Herbert Gunasekera, Military Airlift Command, and Mr. Clive Dirckze of Pest Control all provided invaluable assistance. Dr. J.M. Hanna kindly assisted with the statistical analysis.

\section{References}

Bech C, Mehlum F, Haftorn S (1991) Thermoregulatory abilities in chicks of the Antarctic petrel (Thalassoica antarctica). Polar Biol $11: 233-238$

Fisher HI (1975) Mortality and survival in the Laysan albatross, Diomedea immutabilis. Pac Sci 29:279-300

Grant GS, Paganelli CV, Pettit TN, Whittow GC, Rahn H (1982) Determination of fresh egg mass during natural incubation. Condor 84:121-122

Harrison CS (1990) Seabirds of Hawaii. Comstock, Ithaca, p 57

Howell TR, Bartholomew GA (1961) Temperature regulation in Laysan and Black-footed albatross. Condor 63:185-197

Klaassen M, Bech C (1992) Resting and peak metabolic rates of Arctic tern nestlings and their relations to growth rate. Physiol Zool 65:803-814

Mathiu PM, Dawson WR, Whittow GC (1991) Development of thermoregulation in Hawaiian brown noddies (Anous stolidus pileatus). J Therm Biol 16:317-325

Mathiu PM, Dawson WR, Whittow GC (1994) Thermal responses of advanced embryos and hatchlings of the sooty tern. Condor 96:280-294

Mathiu PM, Whittow GC, Dawson WR (1992) Hatching and the establishment of temperature regulation in the wedge-tailed shearwater (Puffinus pacificus). Physiol Zool 65:583-603

Matsunaga C, Mathiu PM, Whittow GC, Tazawa H (1989) Oxygen consumption of Brown Noddy (Anous stolidus) embryos in a quasi-equilibrium state at lowered ambient temperatures. Comp Biochem Physiol 93A:707-710

Misson BH (1977) The relationships between age, mass, body temperature and metabolic rate in the neonatal fowl (Gallus domesticus). J Therm Biol 2:107-110

Pettit TN, Whittow GC (1983) Water loss from pipped wedge-tailed shearwater eggs. Condor 85:107-109

Pettit TN, Whittow GC (1985) Water loss from pipped eggs of two species of noddies. J Field Ornithol 56:277-280

Pettit TN, Grant GS, Whittow GC, Rahn H, Paganelli CV (1982) Embryonic oxygen consumption and growth in the Laysan and black-footed albatross. Am J Physiol 242R:R121-128

Pettit TN, Whittow GC, Grant GS (1984) Caloric content and energy budget of tropical seabird eggs. In: Whittow GC, Rahn $\mathrm{H}$ (eds) Seabird energetics. Plenum Press, New York, pp 113-137

Steel RGD, Torrie JH (1960) Principles and procedures of statistics. McGraw-Hill, New York, pp 101-111

Swinscow TDV (1981) Statistics at square one. British Medical Association, London

Tazawa H, Wakayama H, Turner JS, Paganelli CV (1988) Metabolic compensation for gradual cooling in developing chick embryos. Comp Biochem Physiol 89A:125-129

Tazawa H, Whittow GC, Turner JS, Paganelli CV (1989) Metabolic responses to gradual cooling in chicken eggs treated with thiourea and oxygen. Comp Biochem Physiol 92A:619-622

Whittow GC (1985) Partition of water loss from the eggs of the sooty tern between the pre-pipping and pipped periods. Wilson Bulletin 97:240-241

Whittow, GC, Tazawa H (1991) The early development of thermoregulation in birds. Physiol Zool 64:1371-1390 